\title{
Association of vectors and environmental conditions during the emergence of Peruvian horse sickness orbivirus and Yunnan orbivirus in northern Peru
}

\author{
María R. Méndez-López ${ }^{1 凶}$, Houssam Attoui $^{2}$, David Florin ${ }^{3}$, Charles H. Calisher ${ }^{4}$, \\ J. Christian Florian-Carrillo ${ }^{5}$, and Stephanie Montero ${ }^{1}$
}

${ }^{1}$ Instituto de Investigación de la Facultad de Medicina Humana, Universidad de San Martín de Porres, Av. Alameda del Corregidor 1561, La Molina, Lima, Perú, mariamendez42@hotmail.com

${ }^{2}$ Department of Vector-Borne Viral Diseases, The Pirbright Institute, Pirbright, Woking, Surrey, United Kingdom ${ }^{3}$ Department of Preventive Medicine and Biometrics, Uniformed Services University of the Health Sciences, Bethesda, MD, U.S.A. ${ }^{4}$ Department of Microbiology, Immunology and Pathology, College of Veterinary Medicine and Biomedical Sciences, Colorado State University, Fort Collins, CO, U.S.A.

${ }^{5}$ Instituto de Medicina Tropical "Daniel A. Carrión”, Universidad Nacional Mayor de San Marcos - Facultad de Medicina. Ciudad Universitaria, Lima, Peru

Received 22 April 2015; Accepted 9 July 2015

\begin{abstract}
Since 1983, cases of diseased donkeys and horses with symptoms similar to those produced by alphaviruses were identified in two departments in northern Peru; however serological testing ruled out the presence of those viruses and attempts to isolate an agent were also unproductive. In 1997, also in northern Peru, two new orbiviruses were discovered, each recognized as a causative agent of neurological diseases in livestock and domestic animals and, at the same time, mosquitoes were found to be infected with these viruses. Peruvian horse sickness virus (PHSV) was isolated from pools of culicid mosquitoes, Aedes serratus and Psorophora ferox, and Yunnan virus (YUOV) was isolated from Aedes scapularis in the subtropical jungle (upper jungle) located on the slope between the east side of the Andes and the Amazonian basin in the Department of San Martín. Both viruses later were recovered from mosquitoes collected above the slope between the west side of the Andes and the coast (Department of Piura) in humid subtropical areas associated with the Piura River basin. In this region, PHSV was isolated from Anopheles albimanus and YUOV was isolated from Ae. scapularis. We discuss the ecology of vector mosquitoes during the outbreaks in the areas where these mosquitoes were found. Journal of Vector Ecology 40 (2): 355-363.
\end{abstract}

Keyword Index: Peru, orbivirus, Peruvian horse sickness orbivirus, Yunnan orbivirus, mosquitoes, Aedes serratus, Aedes scapularis, Psorophora ferox, ecology.

\section{INTRODUCTION}

During a Venezuelan equine encephalitis virus (VEEV) surveillance program in Peru in 1983, attempts to isolate a virus from equids with clinically-observed encephalitis were unsuccessful. During subsequent years, similar but sporadic cases were detected but no virus was isolated. In 1997, an epizootic outbreakinvolving domestic animals (equids, bovids, ovids, and canids) occurred and, using electron microscopy, a reovirus was detected. Later, two new orbiviruses were identified from domestic animals and mosquitoes (Attoui et al. 2009). The orbiviruses (family Reoviridae, genus Orbivirus) Peruvian horse sickness virus (PHSV) and Yunnan orbivirus (YUOV) were isolated from whole blood and brain tissues of sick animals and from chronically infected animals, as well as from mosquitoes. The affected departments were San Martín, adjacent to the northeastern side of the Andes, and Piura, located on the northwest side (Figure 1). In San Martín, most of the affected animals were equids but in Piura bovids were primarily affected.

Phylogenetically, PHSV, the orbivirus identified in vertebrates and in mosquitoes, belongs to the same serotype as Elsey virus, which had been isolated from horses with neurological disease in northern Australia (Melville 2004). PHSV and Elsey viruses share a high degree of sequence identity, particularly in the gene encoding the outer capsid protein VP3 (99\%). Alternatively, Middle Point orbivirus, a virus isolated from an apparently healthy sentinel bovid in northern Australia, and YUOV, although closely related to each other and distinct from PHSV, are distinct serotypes (Cowled et al. 2007). Yunnan orbivirus was originally isolated from Culex tritaeniorhynchus mosquitoes in China (Attoui et al. 2005).

Peru encompasses diverse ecosystems, with 84 of the recognized 114 life zones of the world and 28 of the 34 recognized climates. In these ecosystems, climate events occur non-dramatically but may cause climatic alterations, which benefits or inhibits human development or biological development in general. The aim of this study was to describe the environs in which we found these viruses and vectors in Peru by comparing mosquito abundance with weather data and human activities during years in locations where there were arbovirus infections. 


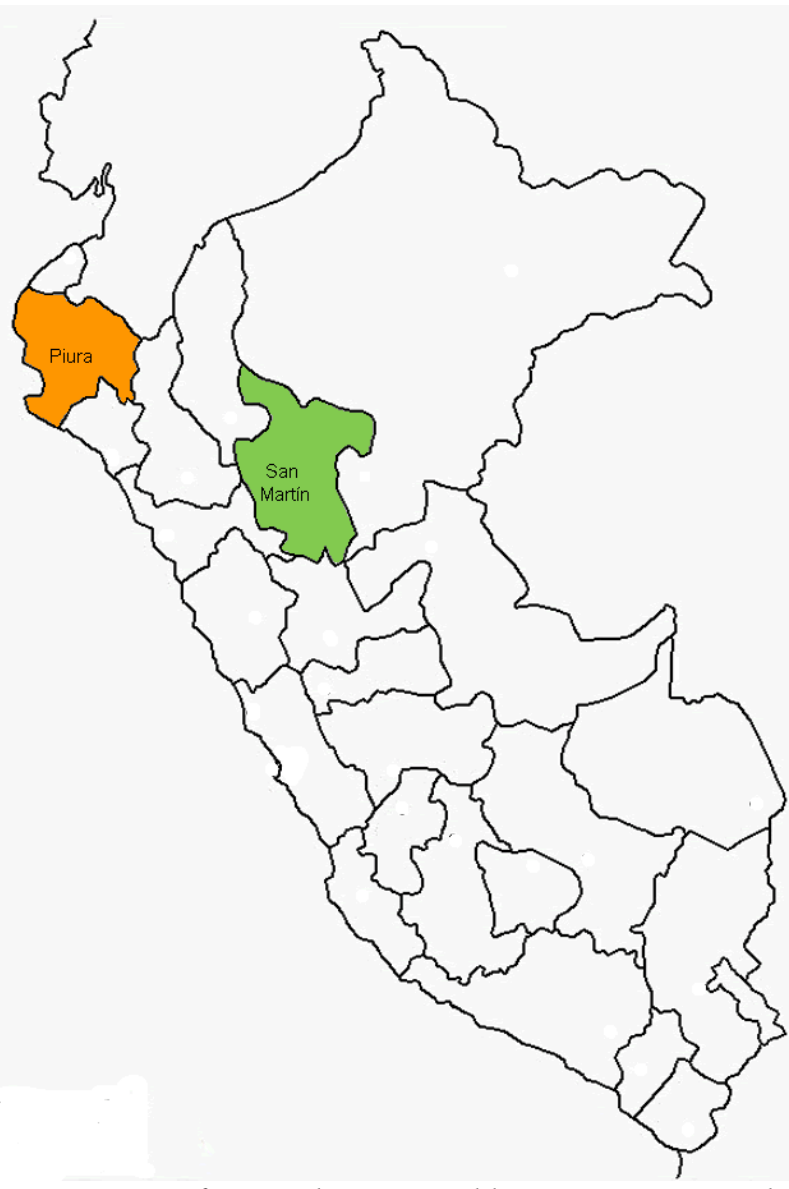

Figure 1. Map of Peru. The principal locations mentioned in the text, Department of Piura and Department of San Martín.

\section{MATERIALS AND METHODS}

\section{Locations}

San Martín. The Department of San Martín occupies an area of $51,253 \mathrm{~km}^{2}$ in northeastern Peru. The Huallaga River basin constitutes the principal watershed of this region and is the focal point of a hydrographic system of 126 rivers. The region is hilly and comprises four morphological zones: (1) a western zone bordering the eastern slope of the Andes, (2) a central zone of wide valleys, with terraces formed by the Huallaga River and its tributaries, (3) a southeast zone, with elevations not exceeding $3,000 \mathrm{~m}$, and (4) a northeast zone of lowlands.

In 1997, an orbiviral disease outbreak appeared in the central zone, associated with the Huallaga River and one of its tributaries, the Mayo River. This area has a predominantly humid tropical climate, ecologically known as "upper jungle," and an altitude between 223-860 m above sea level, a mean temperature between $22^{\circ}$ and $35^{\circ} \mathrm{C}$, and an annual rainfall of $900-1,500 \mathrm{~mm}$. Precipitation levels have two distinct temporal peaks in the basin, the first generally occurs between March and April and the second, usually in October, associated with discharges of tributary rivers. The course of the Huallaga River in these broad valleys is associated with small lagoons and broader flood areas (IIAP 2009).

The region's main economic activity is agriculture. The basin of the Huallaga River has one of the largest areas of natural pastures (more than 36,400 ha) in Peru. Extensive cattle ranching occupies $60 \%$ of this area; raising other livestock is a secondary activity.

Over the past two decades, the rural human population in northeastern Peru has grown rapidly, giving rise to the occupation and exploitation of unprotected forests. In spite of governmental efforts, many regions have suffered indiscriminate logging of large areas, resulting in erosion of soil, landslides, floods, and a decreased seasonal supply of water (Gentry and López-Parodi 1980). Designation of the high forest as a protected zone has failed to save the forest and its biodiversity. One of the areas most affected by the orbivirus epizootic was the upper Mayo River basin, which corresponds to the Rioja and Moyobamba provinces. The human population of the upper Mayo River area, about 140,000, is involved in agriculture, the economic and productive base of the region. The most important products in the area are corn, rice in the lower (irrigated) areas, and coffee in the upper part. The approximately 60,000 residents of the rural areas of the upper Mayo River tend cattle, sheep, pigs, horses, and poultry. In 1997, the cattle population was 150,000 and there were 20,000 sheep, 100,000 pigs, and 8,000 horses. Cattle and sheep spend their days grazing on natural pastures close to the homes of their owners, the pigs feed in the poultry yards, and the horses accompany agricultural operations for transport of firewood, crops, and other products.

Mosquitoes were captured for virus isolation during the outbreak in March, 1997. Collections were made in the secondary forest where horses are allowed to rest in the provinces of Mariscal Cáceres ( $7^{\circ} 10^{\prime} 57.134^{\prime \prime} \mathrm{S}, 76^{\circ} 44^{\prime} 27.151^{\prime \prime}$ W) and Moyobamba (6 $6^{\circ} 28.3278^{\prime \prime}$ S, $76^{\circ} 55^{\prime} 28.4406^{\prime \prime} \mathrm{W}$ and $6^{\circ} 4^{\prime} 0.5412^{\prime \prime} \mathrm{S}, 77^{\circ} 5^{\prime} 18.1494^{\prime \prime} \mathrm{W}$ ). For two consecutive days, 10-11 March, we collected mosquitoes manually from 10:00 to 12:00 and from 16:00 to 19:00, using resting horses as bait and suction tubing by mouth. Mosquitoes collected were placed in plastic cups, covered, and stored in a refrigerator until the next day. They were then identified to species and stored in plastic tubes, each containing an average of 25 mosquitoes. Tubes were then stored in liquid nitrogen for transportation to the laboratory in Lima.

Piura. The Department of Piura, with a total area of 35,892 $\mathrm{km}^{2}$, is located in northwestern Peru, and incorporates a long coast, its weather influenced by the Humboldt current and the periodic warm or cool currents of El Niño/La Niña-Southern Oscillation (ENSO). The Piura River basin comprises an area of approximately $12,200 \mathrm{~km}^{2}$, from its headwaters at 3,600 m above sea level to its mouth at the Pacific Ocean. Ecologically, Piura encompasses the high arid plains of the Andes, with perpetual snow, equatorial dry forest, tropical valleys formed by rivers originating in the basin of the Amazonian high forest, and subtropical deserts along the southern Pacific coast (Rodriguez 2005), all of which interact with the warm current of the El Niño and the cold Humboldt current of the Pacific Ocean.

In the Department of Piura, the average annual humidity is $66 \%$. On the coast, at $100 \mathrm{~m}$ and $500 \mathrm{~m}$ above sea level, the low side of the Piura River basin, rainfall ranges from 10-200 
$\mathrm{mm}$, and at $500 \mathrm{~m}$ to $1,500 \mathrm{~m}$ above sea level, the high side of the Piura River basin, rainfall ranges from 200-800 mm.

At the beginning of 1997, there occurred an anomaly of temperature, reaching record high levels during the epizootic in the months of July and August. The El Niño occurred from December, 1997 to May, 1998 and had a greater impact on the economy and the ecology of Piura than that which occurred in 1982-1983 (Woodman 1998).

The human population of the Piura River basin is more than 900,000 . Almost $40 \%$ of them are active in agriculture, livestock, hunting, and forestry. Floods occur annually in the rainy period, which is concentrated between January and April. The distribution of crops in the basin of the Piura River is related to water availability and weather conditions. Crops raised on the high side of the Piura River basin vary widely.

The areas affected by the epizootic of YUOV in cattle and donkeys in this department were in districts from the contiguous provinces of Ayabaca (Suyo) and Morropón (Yamango), the high side of the Piura River basin, including the border with neighboring Ecuador. During the YUOV epizootic disease season, the area where the largest number of cattle deaths occurred was in the province of Morropón, which has a human population of about 170,000, 56,000 cattle, 35,000 sheep, and 35,000 swine. The Yamango district in eastern Morropón province was the most highly impacted by the epizootic. Cases were recorded in an area located at an altitude of $1,175 \mathrm{~m}$ above sea level where the climate is mainly warm. The months of January-March are relatively cold. Maximum temperature is $25^{\circ} \mathrm{C}$ and minimum $16^{\circ} \mathrm{C}$.
Agricultural activity includes some cattle, equids (mainly donkeys), poultry, and a few sheep. A characteristic of the agricultural activity in Yamango is that during the rainy season cattle are moved to areas at higher altitude where there are lush native grasses. When rains occur the animals are kept in dry quarters called "greenhouses." After the rains, the animals are moved to pens near human abodes where they are fed with dry grass from May to December.

The main economic activity in Suyo involves livestock, with about 7,000 cattle, 17,000 goats, 15,000 poultry, and 1,000 sheep. In this area farmers mainly grow rice and corn, leaving vast uncultivated areas for access by grazing animals. There frequently is trade for Ecuadorian cattle without sanitary controls. In addition, vast expanses of forest here are used by locals for fuel, producing an altered environment. In the affected areas, the rainy season coincides with the highest temperature. In 1997 the temperature reached $27.2^{\circ} \mathrm{C}$ in February. YUOV cases were reported from July to August (dry season) similar to reports from the Department of San Martín but for a shorter period of time (Figure 2). At that time we alerted all of Peru and asked that cases of livestock with neurological symptoms be reported to local health authorities.

Mosquitoes were collected as they were feeding on donkeys in the District of Suyo in Ayabaca Province ( $4^{\circ} 30^{\prime}$ 36.389" S, 80 0' 16.900" W), 14 March 2008, from 17:0019:00. In the District of Yamango ( $5^{\circ} 10^{\prime} 47.914$ " S, $79^{\circ} 45^{\prime}$ $\left.10.882^{\prime \prime} \mathrm{W}\right)$, we attempted to collect mosquitoes on 14 June 2010 during the morning from animals in greenhouses but

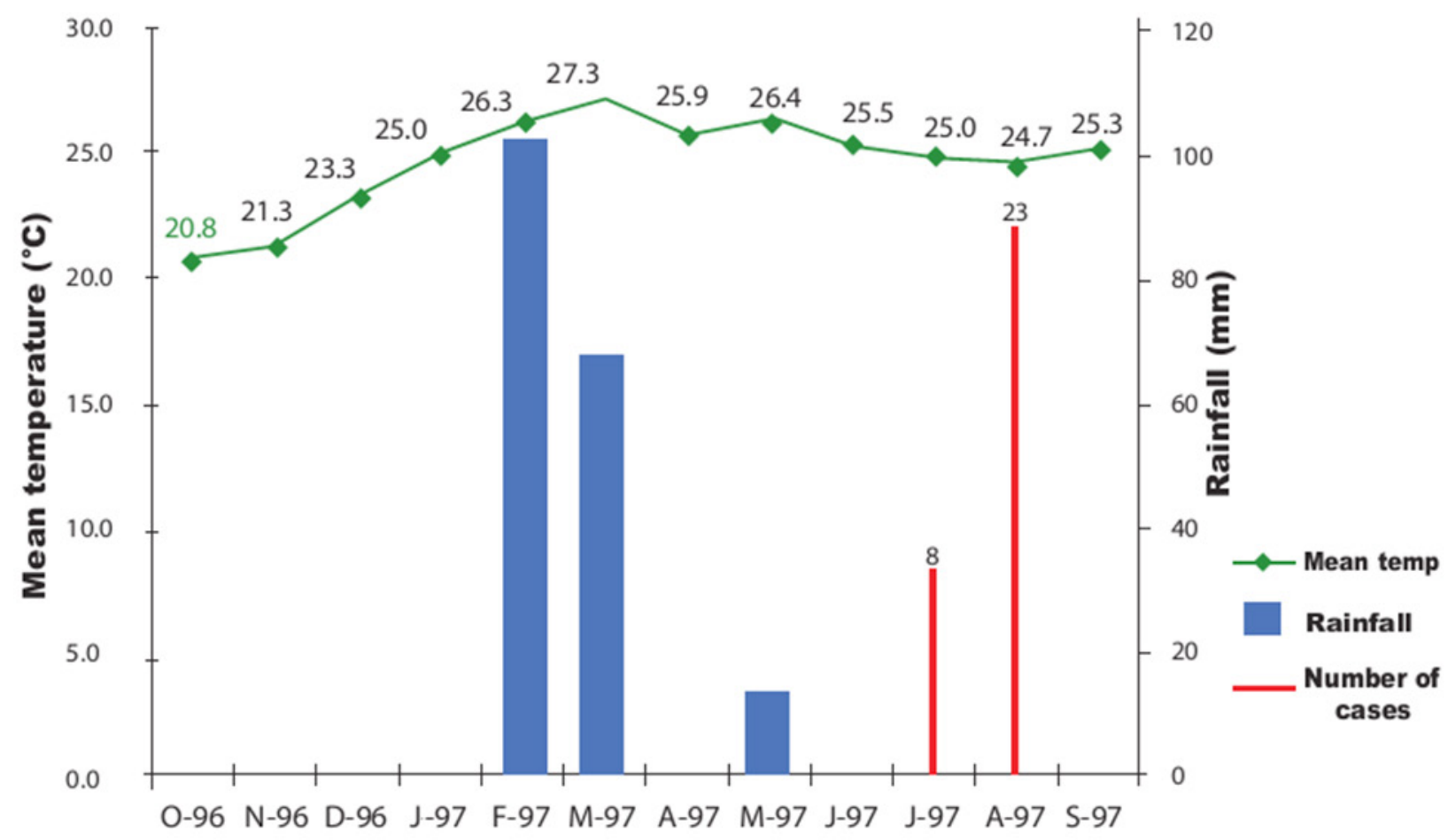

Figure 2. Temperature and rainfall in the Department of Piura, 1996-1997. The graph shows the number of cases of YUOV that occurred after the rainy season. Weather measurements obtained from SENAMHI, Paita Station (Servicio Nacional de Meteorología e Hidrología). 
no mosquitoes were found. Other attempts, on 14 and 15 June 2010, to capture mosquitoes were made from 17:00-19:00, from animals in livestock pens behind houses. The procedure was similar to that mentioned above for the Department of San Martín. Note that at all sites, mosquitoes were allowed to feed and were then collected, so that viruses isolated from mosquitoes likely came from the vertebrate hosts.

\section{Isolation of viruses and amplification in cell culture}

Pooled mosquitoes were homogenized, clarified, and inoculated onto C6/36 (Aedes albopictus mosquito) cells, which were observed for seven days for signs of floating cells (typical effect when C6/36 cells are infected with a dsRNA arbovirus), as previously described (Hurtado-Alendes et al. 2005). Cultures with suspect or obvious cytopathic effects were frozen at $-70^{\circ} \mathrm{C}$ and then passed three more times in C6/36 cells. Usually, suspected positive samples from mosquitoes did not yield clear-cut cytopathic effects even after three passages in C6/36 cells. However, subsequent passages of the majority of these samples in RD (human rhabdosarcoma) cells resulted in clear-cut cytopathic effects. These viruses appeared to replicate slowly in C6/36 cells, a manner different from that of encephalitic alphaviruses but similar to that of other orbiviruses. For many of these orbivirus isolates, it required more than ten days to observe clear-cut cytopathic effects. When the number of infected C6/36 cells increased and formed clusters (30\% of cells), the $12 \mathrm{ml}$ culture bottles were shaken to loosen and disperse the clusters and $4 \mathrm{ml}$ of the suspension were transferred to fresh cultures containing half the number of cells normally used. Infected cells in clusters were larger cells than those altered by aging. Passages were frozen when it was clear that $70 \%$ of them formed clusters.

Viral RNA was extracted from $\mathrm{C} 6 / 36$ and $\mathrm{RD}$ cells by a method standardized for animal samples by separating the detritus by centrifugation at 3,000 rpm x $5 \mathrm{~min}$ and then centrifuging the supernatant fluid at 60,000 rpm x 120 min. The pellet was used for extraction of RNA according to Chomczynski and Sacchi (1987) with some modifications. The extracted RNA was analyzed by $1 \%$ gel electrophoresis containing $0.5 \mathrm{ug} / \mathrm{ml}$ ethidium bromide (Sambrook et al. 1989). Those that showed a suggestive segment profile typical of viruses of the Reoviridae family were sent to the Pirbright Institute in Surrey, United Kingdom, for testing by RT-PCR with specific primers (Attoui et al. 2009).

\section{RESULTS}

The number of mosquitoes collected in San Martín from 1980 to 1997 is summarized in Table 1. In March of 1997, during the outbreak, we collected mosquitoes of 23 species. Only a few more Ae. serratus were collected than in previous years. The most abundant mosquitoes collected were Ae. scapularis and Psorophora cingulata. Midges of the genus Culicoides (family Ceratopogonidae) were also present in the collections. In addition, we found mosquitoes of many species that had not been found in previous years in the same locations during the same seasons (Méndez-López and
Hurtado-Alendes 2009).

In the department of Piura in 1997, during the outbreak we were not able to capture mosquitoes due to the heavy rain and consequent flooding, which made it difficult to reach those areas. In 1998 we found a lower diversity of mosquitoes in the district of Suyo than in previous years. Ae. scapularis was always the predominant species, representing $65.5 \%(\mathrm{~N}=$ 553 ) of the mosquitoes captured. In June, 2010, we found a high number of Ae. scapularis $(\mathrm{N}=162)$ in the district of Yamango, the only mosquitoes found in that season (Table 2).

PHSV was isolated from Ae. serratus and Ps. ferox, sylvatic mosquitoes, and YUOV was isolated from Ae. scapularis, a peri-urban mosquito that is widely distributed. Likewise, in Piura, both viruses were recovered from periurban mosquitoes; YUOV from Ae. scapularis and PHSV from An. albimanus, although there were no cases of PHSV in Piura (Table 3).

\section{DISCUSSION}

More than 3,500 species of mosquitoes have been recognized world-wide, are distributed throughout temperate and tropical regions of the world, and occupy a wide range of aquatic environments. There are about 1,700 species of culicine mosquitoes distributed in 20 genera, with Aedes and Culex including the most common arbovirus vectors (Moraes 2007). Tropical humid climates support mosquitoes of the most diverse species, and many of them transmit infectious agents (Brown et al. 2011). Diseases of humans and other vertebrates often are recognized as zoonoses when the habitats of their vectors and reservoir hosts are disturbed, such as after deforestation (Forattini et al. 1995) or dam building (Liehne et al. 1976). Peru, because of its wide variety of habitats, appears to be ideal for mosquitoes of many varieties. Other than studies of yellow fever virus (Mendez et al. 1984), few broad studies have been conducted in Peru, so that relatively little is known about arboviruses in this country.

The Amazon River is the primary source of fresh water for Peru, and the Andes mountains are the main sources of ecosystem variety. As habitat location influences mosquito presence and vectorial capacity to humans and other vertebrates, habitat changes likely affect transmission of potentially emerging diseases and one of the causes of the dispersion of viruses, particularly arboviruses, is the destruction of the natural habitats of their reservoirs or vectors, as has occurred in Peru.

The orbivirus epizootics in San Martin occurred in the first half of 1997 in almost all the provinces of the department associated with the Huallaga River or the Mayo River, causing the deaths of at least 100 horses, as well as some bovids, ovids, and canids. The epidemiological and virological characteristics of the outbreak have been described (Attoui et al. 2009). PHSV affected only horses but YUOV affected cattle and donkeys. Cattle and dogs from the neighboring Department of Ucayali also were affected.

In the basin of the Mayo River the peak number of cases of PHSV during the outbreak in the rainy season coincided with the highest humidity but not with the highest temperature, 
Table 1. Number of arthropods collected in the upper jungle of the Department of San Martín, 1980-1997 by species and monthyear of collection.

\section{MONTH AND YEAR OF COLLECTION}

\begin{tabular}{|c|c|c|c|c|c|}
\hline SPECIES & Mar-1980 & Mar-1982 & Mar-1983 & Mar-1984 & Mar-1997 \\
\hline Psorophora ciliata & 6 & - & 56 & - & - \\
\hline Psorophora cingulata & - & - & - & - & 120 \\
\hline Psorophora albigenu & - & - & - & - & 12 \\
\hline Psorophora linneata & 25 & - & - & 1 & - \\
\hline Psorophora albipes & 267 & - & - & - & - \\
\hline Psorophora ferox & 10 & 160 & - & - & 115 \\
\hline Psorophora cilipes & 181 & - & - & - & - \\
\hline Psorophora lutzi & - & 77 & - & 33 & 110 \\
\hline Psorophora lannei & - & - & - & 17 & - \\
\hline Haemagogus janthinomys & 2 & 20 & 5 & 2 & 4 \\
\hline Aedes aegypti & - & - & - & - & 10 \\
\hline Aedes fulvus & 141 & 73 & - & - & 50 \\
\hline Aedes upatensis & - & 5 & - & - & - \\
\hline Aedes pennai & - & 1,259 & - & 24 & - \\
\hline Aedes species & - & 1 & - & - & 150 \\
\hline Aedes scapularis & 179 & 204 & - & 15 & 180 \\
\hline Aedes serratus & 7 & 7 & - & 1 & 90 \\
\hline Aedes species & - & - & - & - & 123 \\
\hline Limatus paraensis & - & 3 & - & - & 15 \\
\hline Limatus durhamii & - & 5 & - & 14 & 25 \\
\hline Trichoprosopon brevipes & - & - & 20 & - & - \\
\hline Sabethes belisarioi & 2 & 1 & 6 & 3 & - \\
\hline Sabethes species & - & - & 1 & - & 50 \\
\hline Mansonia pseudotitillans & - & - & 6 & - & - \\
\hline Mansonia venezuelensis & - & - & 10 & - & - \\
\hline Mansonia indubitans & - & - & - & - & 30 \\
\hline Wyeomyia moerbista & - & - & - & 1 & - \\
\hline Anopheles rangeli & - & - & - & - & 90 \\
\hline Coquillettidia venezuelensis & - & - & - & - & 12 \\
\hline Culex insinuatus & - & - & - & - & 10 \\
\hline Culex paraensis & - & - & - & - & 6 \\
\hline Culex (Melanoconion) species & - & - & - & - & 50 \\
\hline Culex species & - & - & - & - & 75 \\
\hline Culicoides species & - & - & - & - & 160 \\
\hline Simulium species & - & - & - & - & 70 \\
\hline Total species & 10 & 12 & 07 & 10 & 23 \\
\hline Total mosquitoes & 820 & 1,815 & 104 & 111 & 1,557 \\
\hline
\end{tabular}


Table 2. Mosquitoes collected on the high side of the Piura River: Ayabaca (Suyo) and Morropón (Yamango), provinces, Peru, 1981-2010, by species and month-year of collection.

LOCATION

\begin{tabular}{lccccccc}
\cline { 2 - 7 } \multicolumn{1}{c}{ SPECIES } & $\begin{array}{c}\text { Suyo } \\
\text { (Mar-1981) }\end{array}$ & $\begin{array}{c}\text { Suyo } \\
\text { (Feb-1983) }\end{array}$ & $\begin{array}{c}\text { Suyo } \\
\text { (Jun-1996) }\end{array}$ & $\begin{array}{c}\text { Suyo } \\
\text { (Aug-1996) }\end{array}$ & $\begin{array}{c}\text { Suyo } \\
\text { (Jan-1998) }\end{array}$ & $\begin{array}{c}\text { Suyo } \\
\text { (Mar-2008) }\end{array}$ & $\begin{array}{c}\text { Yamango } \\
\text { (Jun-2010) }\end{array}$ \\
\hline Anopheles calderoni & 923 & 81 & 72 & 37 & 0 & 6 & 0 \\
An. albimanus & 454 & 1,531 & 581 & 30 & 65 & 1,140 & 0 \\
An. pseudopunctipennis & 12 & 0 & 0 & 18 & 0 & 70 & 0 \\
Aedes scapularis & 230 & 77 & 1,180 & 61 & 6 & 186 & 162 \\
Ae. taeniorhynchus & 0 & 34 & 154 & 107 & 0 & 0 & 0 \\
Culex quinquefasciatus & 40 & 16 & 154 & 107 & 7 & 0 & 0 \\
Culex species & 0 & 0 & 47 & 5 & 0 & 43 & 0 \\
$\begin{array}{l}\text { Culex (Melanoconion) } \\
\text { species }\end{array}$ & 6 & 0 & 0 & 43 & 0 & 101 & 0 \\
\hline
\end{tabular}

which occurs in October. On the other hand, isolated cases of YUOV were found between April and August, during the season called dry or cold, when temperature and humidity do not vary but rains decrease (Figure 3).

It is likely that the epidemiology of PHSV follows ecological patterns associated with the characteristics of the vectors, similar to those of other arboviruses (Soldán and Gonzales-Scarano 2005). The PHSV outbreak in 1997 peaked between January and May, with about half the cases occurring in March, coincident with the highest humidity of the year (85.5\%). Ps. ferox and Ae. serratus have historically been collected in natural woodlots throughout the Americas (Forattini et al. 1968). The biological cycles of these mosquitoes are highly dependent on temperature, relative humidity, and rainfall (Loetti et al. 2007). However, in the areas affected by the PHSV outbreak, it was uncommon to find them feeding on horses in large numbers until 1997. During previous entomological investigations in the same departments, we observed that these mosquitoes were also present (MendezLopez, unpublished observations), but we did not isolate
PHSV from them nor did we find mosquitoes of a wide variety of species, even during March (Table 3). It is likely that other factors, such as mosquito overwintering strategies that favor an increase in the adult population of orbivirus vectors, can ensure the interrelation with the host and the reservoir for subsequent epizootic outbreaks. In 1996, in the Province of Rioja, the lowest levels of precipitation in the previous 30 years occurred. This situation could have created an environment in which the eggs of some mosquitoes resisted desiccation and eclosed when the precipitation increased in 1997 (Crans 2004, Clements 1992). Although many variables can affect mosquito population dynamics, one reasonable hypothesis for the increase of mosquito species in the area is the increased level of precipitation in October, 1996 along the tributary rivers of Mayo River, causing considerable flooding for a month afterwards. These conditions, along with high temperatures, created optimal conditions for oviposition by a variety of mosquito vectors.

Yunnan virus is transmitted by Ae. scapularis, a mosquito dependent on variable temperature, relative humidity, and

Table 3. Species of mosquitoes infected with Peruvian horse sickness virus (PHSV) or Yunnan virus (YUOV) during a 1997 outbreak, and from 1998 and 2010 samplings in the Departments of San Martín and Piura. The 13 orbivirus strains were isolated from mosquitoes. Only YUOV was recovered from Ae. scapularis on the coast and in the jungle. PHSV was recovered from sylvatic mosquitoes in the jungle and from An. albimanus on the coast.

\begin{tabular}{lccccc}
\hline Species (No. of pools) & Department & Date & Province & Locality & Virus \\
\hline Ae. serratus (1) & San Martín & March 1997 & Moyobamba & Jepelacio & PHSV \\
Ps. ferox (2) & San Martín & March 1997 & Moyobamba & Habana & PHSV \\
Ae. scapularis (2) & San Martín & March 1997 & Moyobamba & Jepelacio & YUOV \\
Ae. scapularis (2) & San Martín & March 1997 & Mariscal Cáceres & Juanjui & YUOV \\
Ae. scapularis (1) & Piura & Jan 1998 & Ayabaca & Suyo & YUOV \\
An. albimanus(3) & Piura & March 2008 & Ayabaca & Suyo & PHSV \\
Ae. scapularis (2) & Piura & June 2010 & Morropón & Yamango & YUOV \\
\hline
\end{tabular}




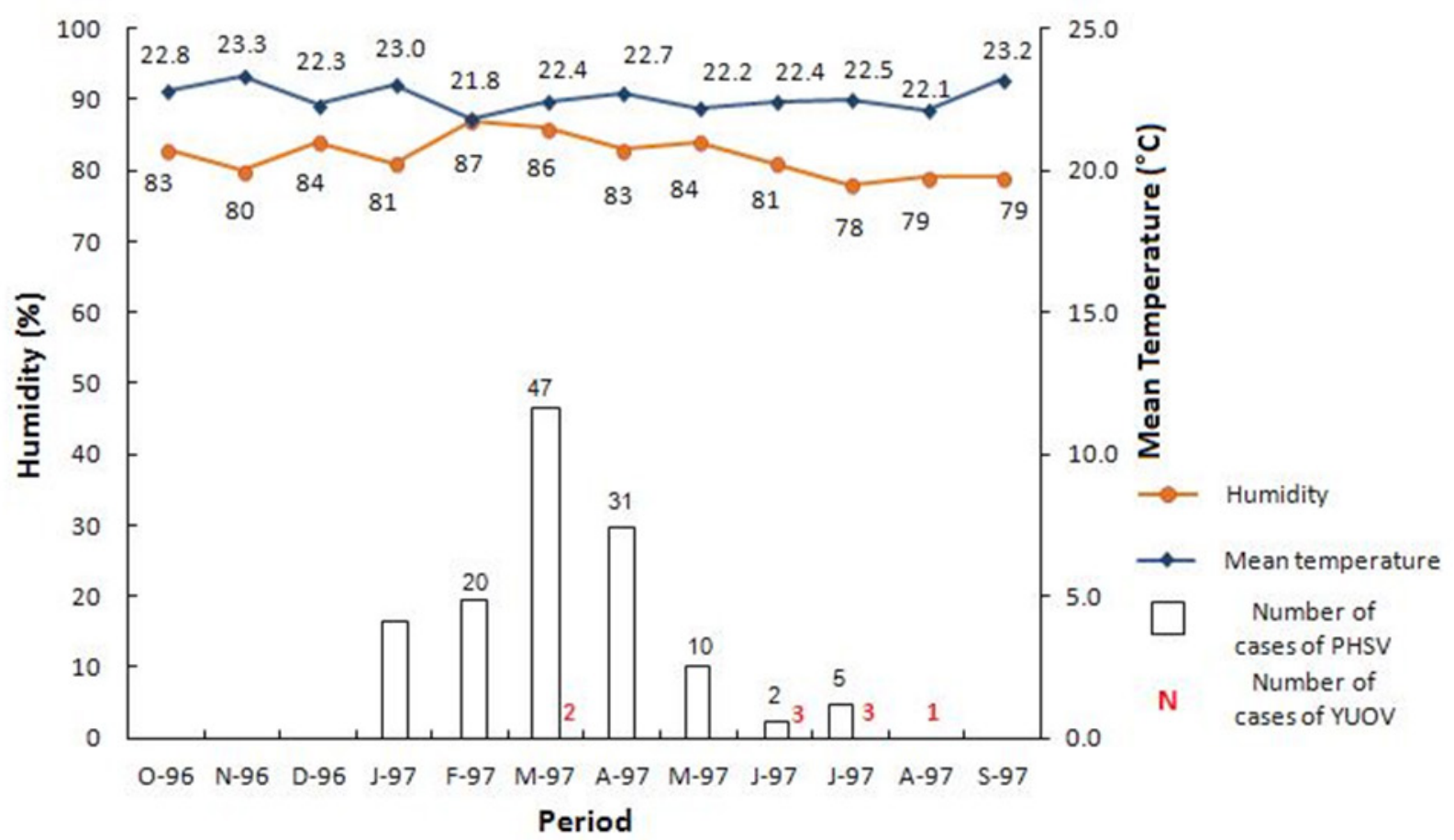

Figure 3. Temperature and humidity in the Department of San Martín, 1997. The graph shows the number of cases during the outbreak of Peruvian horse sickness virus (PHSV) and Yunnan virus (YUOV). Weather measurements obtained from SENAMHI, Moyobamba Station (Servicio Nacional de Meteorología e Hidrología, Moyobamba, Peru).

rainfall associated with the ecology of certain locations, vegetation coverage, and modified environments (Guimaraes et al. 2000, Forattini and Gomes 1988) for population increases, with wide distribution in secondary vegetation and peridomiciliary habitats (Diéguez et al. 2005, Méndez et al. 2001). This mosquito is present in the diverse environments of Peru and in the continent as a whole (Méndez et al. 2001, Reinert et al. 2005). At the end of March, 1997, the intensity of the El Niño began to increase, with temperatures increasing throughout the year and even into April, 1998 (Galarza and Kámiche 2012). In this study, Ae. scapularis were captured from bovids both during the day and, particularly, in the evening, and from other domestic animals (Forattini and Gomes 1988).

Capture of mosquitoes in the Piura River basin has been a routine activity done by our laboratory during surveillance for Venezuelan equine encephalitis virus when the weather creates transient flooding of rice paddies. In January, 1998, the high side of the river was still experiencing heavy rain due to the El Niño, and we were unable to capture many mosquitoes and did not isolate virus from the few we did capture. In March, 2008, in a resting place of bovids in Suyo District, we found high densities of An. albimanus and Ae. scapularis. That year we recovered PHSV for the first time from An. albimanus and YUOV from Ae. scapularis in that location. Subsequently in Yamango, in June, 2010 (dry season), we recovered YUOV from Ae. scapularis (Table 2). However, after the epizootic of 1997, YUOV was isolated sporadically from mosquitoes and bovids on the high side of the Piura River. It is likely that in these places the virus was enzootic.

On the low side of the river, during the rainy seasons and when the highest temperature $\left(34^{\circ} \mathrm{C}\right.$ in March) was observed, we captured Ae. scapularis, mostly in the salt water areas of the coast. The captures were made mainly using biting collections from burros, and these mosquitoes were even in greater numbers than in the jungle of San Martín. No arboviruses were isolated in those years (Table 3).

It is possible that the transmission of Middle Point and Yunnan viruses in Australia, China, and Peru involves vectors with similar bionomic requirements for their circulation in widely disparate geographic areas, all of them located in the intertropic zone. Arthropods depend on local levels of temperature, humidity, and precipitation for reproduction and on overall ecological aspects for their maintenance and distribution (Lord 2004); these areas may have more similarities than are currently recognized.

Another possible variable for the emergence of PHSV and YUOV may be human activities. Deforestation that generates extensive beaches in the hydrography of the Huallaga River and the Mayo River and their tributaries during the rainy season, are appropriate for oviposition by female mosquitoes of various species, including vectors of arboviruses identified in similar ecological zones (Aguilar et al. 2007). Mosquitoes of four species of the genus Psorophora are likely to be favored under such conditions (Table 2). Excessive rains cause overflows in the river basins, leading to the development of 
mosquitoes of this genus in the bends of the Huallaga River. Ae. serratus and Ps. ferox living in the forest environment have little possibility of moving to open land and they probably infect resting horses during the day.

It is known that the Amazon Basin has the highest prevalence of arboviruses in the world, because their natural cycles involve jungle mosquitoes and vertebrate reservoirs, including birds and rodents (Turell et al. 2005, Ferro et al. 2003). Based on our surveillance program, Ae. scapularis appears to be the primary vector of YUOV in this area. These mosquitoes are also present in contiguous saline areas on the low side of Piura River, but no cases of undiagnosed encephalitis have been reported there. Considering the wide distribution of these mosquitoes in South America, YUOV may already be present in countries bordering Peru.

Until now, it has not been possible to determine the role of An. albimanus in the transmission of PHSV, since there have been no reports of sick horses in the area where PHSV was recovered from these mosquitoes. In January, 1996, during surveillance for arboviruses, it was found that some pools of An. albimanus were infected with a then-unidentified virus, with rice cultivation being the major contributor to the high density of this vector at the collection site. Subsequent studies showed that the virus was PHSV. Additional studies are needed in order to understand the economic impact of these orbiviruses, to determine the seasonal conditions leading to amplification of these viruses, and to understand the complexities of the eco-epidemiologic situation with regard to the interrelations of host, vector, and virus.

\section{Acknowledgments}

We thank Mr. Roberto Fernandez, entomologist NAMRU-6, Lima, and Mr. Walter León, entomologist from National Institute of Health, Lima, for providing the taxonomic placement of the mosquitoes we collected. This study was funded by The Faculty of Medicine of San Martín de Porres University (USMP) Lima-Peru, project E100012010042.

\section{REFERENCES CITED}

Aguilar, P., R. Robich, M. Turrell, M. O'Guinn, T. Klein, A. Huaman, C. Guevara, Z. Ríos, R.B. Tesh, D.M. Watts, J. Olson, and S.C. Weaver. 2007. Endemic eastern equine encephalitis in the Amazon region of Peru. Am. J. Trop. Med. Hyg. 76: 293-298.

Attoui, H., M.R. Méndez-López, S. Rao, A. HurtadoAlendes, F. Lizaraso-Caparo, F.M. Jaafar, A.R. Samuel, M. Belhouchet, L.I. Pritchard, L. Melville, R.P. Weir, A.D. Hyatt, S.S. Davis, R. Lunt, C.H. Calisher, R.B. Tesh, R. Fujita, and P. Mertens. 2009. Peruvian horse sickness virus and Yunnan orbivirus, isolated from vertebrates and mosquitoes in Peru and Australia. Virology 394: 298-310.

Attoui, H., F. Mohd Jaafar, M. Belhouchet, N. Aldrovani, S. Tao, B. Chen, G. Liang, R.B. Tesh, P. de Micco, and X. de Lamballerie. 2005. Yunnan orbivirus, a new orbivirus species isolated from Culex tritaeniorhynchus mosquitoes in China. J. Gen. Virol. 86: 3409-3417.

Brown, J.E., C.S. McBride, P. Johnson, S. Ritchie, C. Pauppy, H. Bossin, J. Lutomiah, I. Fernandez-Salas, A. Ponlawat, A.J. Cornel, W.C. Black $4^{\text {th }}$, N. Gorrochotequi-Escalante, L. Urdaneta-Marquez, M. Sylla, M. Slotman, K.O. Murray, C. Walker, and J.R. Powell. 2011. Worldwide patterns of genetic differentiation imply multiple 'domestications' of Aedes aegypti, a major vector of human diseases. Proc. Biol. Sci. 278: 2446-2454.

Chomczynski, P. and N. Sacchi. 1987. Single-step method of RNA isolation by acid guanidinium thiocyanate-phenolchloroform extraction. Anal. Biochem. 162:156-159.

Clements, A. 1992. The Biology of Mosquitoes: I. Development, Nutrition and Reproduction. London: Chapman \& Hall. 509 pp.

Cowled, C., L. Melville, R. Weir, S. Walsh, A. Hyatt, R. Van Driel, S. Davis, A. Gubala, and D. Boyle. 2007. Genetic and epidemiological characterization of Middle Point orbivirus, a novel virus isolated from sentinel cattle in northern Australia. J. Gen. Virol. 88: 3413-3422.

Crans, W.J. 2004. A classification system for mosquito life cycles: life cycle types for mosquitoes of the northeastern United States. J. Vector Ecol. 29: 1-10.

Diéguez, L., V. Mentor, J. Peña, and M. Rivero. 2005. Presencia de la familia Culicidae en el enclave turístico Santa Lucía, Camagüey y su relación con enfermedades de importancia médico-veterinaria. Arch. Méd. de Camagüey. 9: 1-13.

Ferro, C., J. Boshell, A. Moncayo, M. Gonzalez, M. Ahumada, and W. Kang. 2003. Natural enzootic vectors of Venezuelan equine encephailitis virus, Magdalena Valley, Colombia. Emerg. Infect. Dis. 9: 49-54.

Forattini, O.P. and A. de C. Gomes. 1988. Biting activity of Aedes scapularis (Rondani) and Haemagogus mosquitoes in Southern Brazil (Diptera: Culicidae). Rev. Saude Publ. 22: 84-93.

Forattini, O.P., I. Kakitani, E. Massad, and D. Marucci. 1995. Studies on mosquitoes (Diptera: Culicidae) and anthropic environment. 9- Synanthropy and epidemiological vector role of Aedes scapularis in South-Eastern Brazil. Rev. Saude Publ. 28: 395-399.

Forattini, O.P., O. Sousa, and E. Rabello. 1968. Investigações sôbre o comportamento de formas adultas de mosquito silvestres no estado de São Paulo, Brasil. Rev. Saude Publ. 2: 111-173.

Galarza, E. and J. Kámiche. 2012. Informe Técnico 1. Impactos del Fenómeno El Niño (FEN) en la economía regional de Piura, Lambayeque y La Libertad- Proyecto Seguros para la Adaptación al Cambio Climático. Deutsche Gesselschaft für Internationale Zusammenarbeit (GIZ) GmbH. Lima. http://seguros.riesgoycambioclimatico. org/DocInteres/informetecnico1.pdf

Gentry, A. and J. López-Parodi. 1980. Deforestation and increased flooding in the upper Amazon. Science 210: 1354-1356.

Guimaraes, A., R. Pinto de Mello, C. Macedo, and C. Gentile. 2000. Ecology of mosquitoes (Diptera: Culicidae) in areas of Serra do Mar State Park, State of Sao Paulo, 
Brazil. I - Monthly frequency and climatic factors. Mem. Inst. Oswaldo Cruz 95: 1-16.

Hurtado-Alendes, A., M. Méndez-López, and R. Fujita. 2005. Determinación electroforética del genoma de un virus asociado a encefalitis equina en el departamento de San Martín. Horiz. Méd. 5: 8-12.

Instituto de Investigaciones de la Amazonía Peruana (IIAP). 2009. Las potencialidades y limitaciones del departamento de San Martín. Zonificación ecológica económica de la región San Martín. Hidrografía. Instituto de Investigaciones de la Amazonía Peruana. Lima: Punto y Grafía SAC. 71 pp.

Liehne, P., N. Stanley, M. Alpers, and C. Liehne. 1976. Ord River arboviruses--the study site and mosquitoes. Austral. J. Exp. Biol. Med. Sci. 54: 487-497.

Loetti, V., N. Burroni, and D. Vezzani. 2007. Seasonal and daily activity patterns of human-biting mosquitoes in a wetland system in Argentina. J. Vector Ecol. 32: 358-365.

Lord, C. 2004. Seasonal population dynamics and behavior of insects in models of vector-borne pathogens. Physiol. Entomol. 29: 214-222.

Melville, L. 2004. Elsey virus - an isolate of Peruvian horse sickness virus? Animal Health News from the Northern Territory 35: 1 .

Mendez, M.R., S. Sanchez, C.H. Calisher, and J.S. Lazuick. 1984. A continuing focus of yellow fever in the Apurimac River Valley, Ayacucho and the first isolation of yellow fever virus in Peru. Bull. PanAm. Hlth. Org. 18:172-179.

Méndez, W., J. Liria, J. Navarro, C.Z. García., J.E. Freier, R. Salas, S.C. Weaver, and R. Barrera. 2001. Spatial dispersion of adult mosquitoes (Diptera: Culicidae) in a sylvatic focus of Venezuelan equine encephalitis virus. J. Med. Entomol. 38: 813-821.
Méndez-López, M. and A. Hurtado-Alendes. 2009. Vigilancia de Arbovirus en el Departamento de Piura. Perú-2008. Horizonte Médico 2: 67-74.

Moraes, T. 2007. Emergent arboviruses in Brazil. Rev. Soc. Bras. Med. Trop. 40: 224-229.

Reinert, J., R. Harbach, and M. Mureb. 2005. Checklist of aedine mosquito species (Diptera, Culicidae, Aedini) occurring in middle and South America (south of the United States) reflecting current generic and subgeneric status. Rev. Brazil Entomol. 49: 249-252.

Rodríguez, R., A. Mabres, B. Luckman, M. Evans, M. Masiokas, and T. Ektvedt. 2005. "El Niño" events recorded in dry forest species of the lowlands of northwest Peru. Dendrochronologia 3: 181-186.

Sambrook, J., E. Fritsch, and T. Maniatis. 1989. Molecular Cloning: A Laboratory Manual, 2nd ed. Cold Spring Harbor, NY. Cold Spring Harbor Laboratory Press.

Soldán, S. and F. Gonzales-Scarano. 2005. Emerging infectious diseases: The Bunyaviridae. J. Neurovirol. 5: 412-423.

Turell, M., M. O’Guinn, J. Jones, M. Sardelis, D.J. Dohm, D.M. Watts, R. Fernandez, A. Travassos da Rosa, H. Guzman, R. Tesh, C.A. Rossi, V. Ludwig, J.A. Mangiafico, J. Kondig, L.P. Wasieloski, Jr., J. Pecor, M. Zyzak, G. Schoeler, C.N. Mores, C. Calampa, J.S. Lee, and T.A. Klein. 2005. Isolation of viruses from mosquitoes (Diptera: Culicidae) collected in the Amazon basin region of Peru. J. Med. Entomol. 42: 891-898.

Woodman, R. 1998. El fenómeno El Niño y el clima en el Perú. In El Perú en los albores del siglo XXI/2. Ediciones del Congreso del Perú, Lima. 